\title{
Redescription of Monticellius indicum Mehra, 1939 (Digenea: Spirorchiidae) from the Heart of Green Sea Turtles (Chelonia mydas) in Costa Rica
}

\author{
Mario Santoro*,1, Ellis C. Greiner ${ }^{2}$, Juan Alberto Morales ${ }^{1}$ and Beatriz Rodríguez-Ortíz ${ }^{3}$ \\ ${ }^{I}$ Departamento de Patología, Escuela de Medicina Veterinaria, Universidad Nacional, PO Box 86, Heredia 3000, \\ Costa Rica \\ ${ }^{2}$ Department of Pathobiology, College of Veterinary Medicine, University of Florida, Gainesville, Florida 32611 \\ ${ }^{3}$ Laboratorio de Helminthología, Facultad de Microbiología, Universidad de Costa Rica, San José, Costa Rica
}

\begin{abstract}
Monticellius indicum Mehra, 1939, is redescribed from the heart of green sea turtles (Chelonia mydas) at Tortuguero National Park, Caribbean coast of Costa Rica. Of the 40 green turtles examined, only 5 (12.5\%) were infected with a mean intensity of 1.6. Our specimens are consistent with the original description based on a single fluke from the heart of the same host species in the Arabian Sea, Pakistan, but our redescription provides an unreported range of variation while adding new information about acetabulum structure and egg morphology.
\end{abstract}

\section{INTRODUCTION}

Cardiovascular infections by digenetic trematodes belonging to Spirorchiidae Stunkard, 1921, have been recorded worldwide from 4 sea turtles including black (Chelonia mydas agassizii), green (Chelonia mydas), hawksbill (Eretmochelys imbricata) and loggerhead (Caretta caretta) [1,2]. Smith [1] reported a total of 18 species from the cardiovascular system of green turtles, but a few of those were considered synonyms and to date the validity of some taxa is questionable [3]. Several of those genera or species descriptions were based only on a single specimen. This is the case for the only 2 known species of the Monticellius: M. similis, Price, 1934 and M. indicum, Mehra, 1939. Since their description from green turtles, neither species has ever been recorded again. Only recently 3 specimens of $M$. indicum have been collected from the green turtles of Brazil [4]. In this paper, $M$. indicum is redescribed on the basis of specimens collected from the heart of C. mydas at Tortuguero National Park, Costa Rica. New features and the range of variation for this species are recorded.

\section{MATERIALS AND METHODOLOGY}

From June to September 2003 and 2004, the heart and great vessels of 40 nesting green turtles (curved carapace length ranged from 92 to $111 \mathrm{~cm}$ ) found dead on the beach of Tortuguero National Park, on the northeast Caribbean coast of Costa Rica were examined for parasites following the methods described by Greiner et al. [5]. Specimens were placed in tap water and refrigerated overnight, fixed in AFA (alcohol-formalin-acetic acid), stained in Mayer's acid carmine, mounted in Canada balsam, and studied by light microscopy. Measurements are reported in micrometers with the mean followed by the range in parentheses. Forebody is

*Address correspondence to this author at the Departamento de Patología, Escuela de Medicina Veterinaria, Universidad Nacional, PO Box 86, Heredia 3000, Costa Rica; Tel/Fax: (506) 2600849; E-mail: marisant@libero.it the distance from anterior end to anterior edge of acetabulum. Prevalence and intensity are reported according to the definitions by Bush et al. [6]. Figures were drawn with the aid of a camera lucida. Specimens were deposited in the Harold W. Manter Laboratory of Parasitology (HWML), University of Nebraska State Museum, Lincoln, Nebraska, U.S.A.; United States National Parasite Collection (USNPC), Beltsville, Maryland, U.S.A.; and Colección Helmintológica de Costa Rica (CHCR), San José, Costa Rica.

\section{RESULTS}

Eight specimens of $M$. indicum were collected from the heart of 5 of the 40 green turtles examined for parasites. Our description is based on 6 mature specimens. Complete morphometric measurements are listed in Table $\mathbf{1}$ along with those by Mehra [7] and Werneck et al. [4].

\section{Taxonomic Description}

Monticellius indicum Mehra, 1939 (Fig. 1(1-3)).

Body thin, narrow and elongated with rounded extremes. Tegument unspined. Body 3,098 $(2,295-4,284)$ long by 351 (214-571) wide at the midbody level. Forebody 1,142 (8361,632) long. Oral sucker subterminal, protrusible, cup shaped, 162 (112-206) long by 127.5 (82-194) wide. Prepharynx and pharynx absent. Esophagus 421 (309-586) long, surrounded by glandular cells anteriorly to cecal bifurcation. Esophagus bifurcates far anterior to acetabulum, occupies $13.8 \%(11-15.5 \%)$ of body. Ceca extends close to posterior end of the body. Acetabulum circular, 241 (184-326) long by 229 (122-326) wide, pedunculated, located in anterior third of the body, between cecal bifurcation and anterior testis, armed with a single circle of minute margined spines. Acetabulum spines $(\mathrm{n}=12) 11(7-12)$ long. Testes 5-6, lobed, $(\mathrm{n}=12) 133$ (74-268) long by 167 (64-286) wide, with irregular margins forming a single linear row in intercecal space between posterior margin of acetabulum and anterior margin of external seminal vesicle, occupy $26 \%$ (20.6$35.7 \%$ ) of body. External seminal vesicle elongated 178 
Table 1. Measurements of Monticellius indicum Mehra, 1939 from Green Turtles, Chelonia mydas*

\begin{tabular}{|c|c|c|c|}
\hline Character & This Study; $n=6$ & Mehra, 1939; $\mathbf{n}=1$ & Werneck et al., 2008; $\mathrm{n}=3$ \\
\hline Geographical Locality & Caribbean Sea, Tortuguero (Costa Rica) & Arabian Sea, Karachi (Pakistan) & Ubatuba, São Paulo State (Brazil) \\
\hline Site & Heart & Heart Ventricle & Heart \\
\hline Body length & $3,098(2,295-4,284)$ & 3,000 & $4,535.7(3,666-5,646.6)$ \\
\hline Body width & $351(214-571)$ & 400 & $390.1(358.7-432.7)$ \\
\hline Oral sucker length & $162(112-206)$ & 144 & $132.2(86.3-185.4)$ \\
\hline Oral sucker width & $127.5(82-194)$ & 148 & $172.5(1,44.5-1,94.7)$ \\
\hline Acetabulum length & $241(184-326)$ & 256 (diameter) & $239.3(164-318.4)$ \\
\hline Acetabulum width & $229(122-326)$ & - & $165.1(131-194.4)$ \\
\hline Acetabulum spine length & $11(7-12), n=12$ & - & - \\
\hline Esophagus length & $421(309-586)$ & 240 & $418.8(338-513.1)$ \\
\hline Testes number & $5-6, n=5$ & 5 & 5 \\
\hline Testes length & $133(74-268), n=12$ & 160-176 (diameter range) & $179.8(110.9-227)$ \\
\hline Testes width & $167(64-286), \mathrm{n}=12$ & - & $187.5(134.7-276.1)$ \\
\hline $\begin{array}{c}\text { External seminal vesicle } \\
\text { length }\end{array}$ & $178(136-222)$ & 190 & - \\
\hline $\begin{array}{c}\text { External seminal vesicle } \\
\text { width }\end{array}$ & $85(70-111)$ & 60 & - \\
\hline Cirrus sac length & $728(612-1,020)$ & 720 & $713.4(517.8-868.8)$ \\
\hline Cirrus sac width & $62(52-74)$ & 75 & $76.4(66.8-94.1)$ \\
\hline Ovary length & $402(306-541)$ & 400 & $474.3(450-517.7)$ \\
\hline Ovary width & $135(74-235)$ & 160 & $162.8(122.8-220.9)$ \\
\hline Egg length & $174(168-180), n=2$ & 162 & - \\
\hline Egg width & $22, \mathrm{n}=2$ & 21 & - \\
\hline Forebody & $1,142(836-1,632)$ & 1,056 & - \\
\hline \multicolumn{4}{|l|}{ Distance From: } \\
\hline Acetabulum to posterior end & $1,773(1,326-2,550)$ & 1,950 & - \\
\hline Anterior testis to anterior end & $1,442(1,102-1,938)$ & - & - \\
\hline $\begin{array}{c}\text { Posterior testis to posterior } \\
\text { end }\end{array}$ & $862(734-1,061)$ & 1,040 & - \\
\hline $\begin{array}{c}\text { External seminal vesicle to } \\
\text { posterior end }\end{array}$ & $829(638-1,020)$ & 910 & - \\
\hline Ovary to posterior end & $316(205-479)$ & 390 & - \\
\hline Genital pore to posterior end & $260(198-420)$ & 360 & - \\
\hline $\begin{array}{l}\text { Vitelline reservoir to } \\
\text { posterior end }\end{array}$ & $255(148-408)$ & 180 & - \\
\hline
\end{tabular}

*Measurements are reported in micrometers with the mean followed by the range in parentheses. 

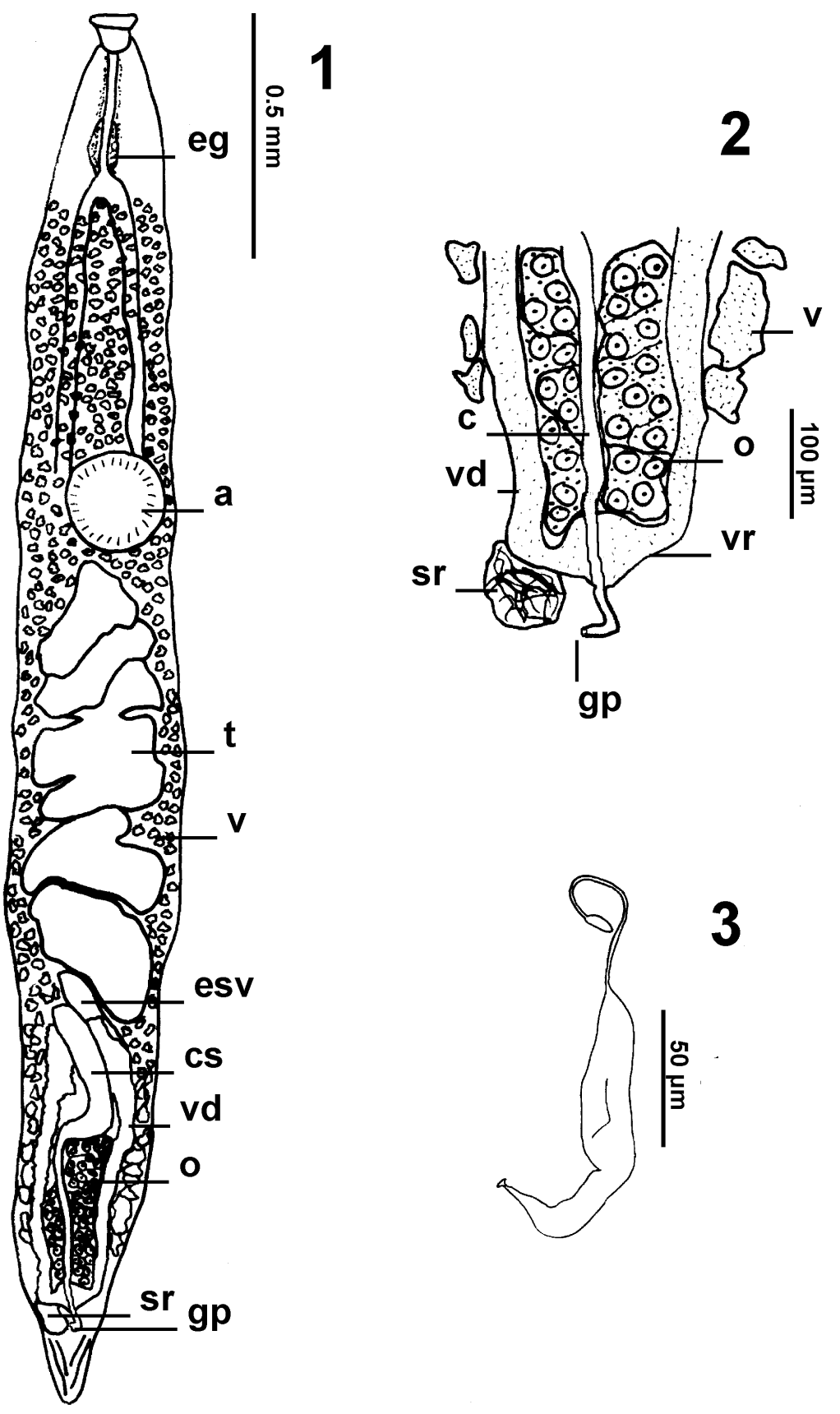

Fig. (1). Monticellius indicum adult specimen. 1. Ventral view of the entire specimen. a, acetabulum; cs, cirrus sac; eg, esophageal glands; esv, external seminal vesicle; gp, genital pore; o, ovary; sr, seminal receptacle; t, testis; v, vitelline follicle; vd, vitelline duct. 2. Terminal genitalia. c, cirrus; gp, genital pore; o, ovary; sr, seminal receptacle; v, vitelline follicle; vd, vitelline duct; vr, vitelline reservoir. 3. Egg.

(136-222) long by 85 (70-111) wide, located between posterior testis and basal portion of cirrus sac. Cirrus sac well developed 728 (612-1,020) long by 62 (52-74) wide, S-shaped, with large internal seminal vesicle followed by ejaculatory duct and surrounded by prostatic cells. Genital pore median, at vitelline reservoir level. Ovary lobed, intercecal 402 (306-541) long by 135 (74-235) wide, located in posterior third of the body, extending from basal part of cirrus sac to anterior margin of vitelline reservoir. Seminal receptacle dextral, posterior to ovary. Laurer's canal and Mehlis' gland not found. Vitelline follicles intra- and extracecal extending from cecal bifurcation to ovary. In pretesticular zone, vitelline follicles occupy entire field. Vitelline ducts arising close to external seminal vesicle area unite to 
form a reservoir posterior to ovary. Uterus contains a single hook-shaped egg with unequal terminal bipolar processes. Eggs $(n=2) 174(168-180)$ long by 22 wide. Polar processes are a tiny circular structure on one end and a large filamentous process with a conspicuous terminal thickening on the other end. Excretory vesicle Y-shaped with excretory pore sub-terminal.

\section{Taxonomic Summary}

\section{Host}

Green sea turtle, Chelonia mydas Linnaeus, 1758 (Testudines: Cheloniidae).

\section{Locality and Collection Dates}

Tortuguero National Park (10³2'27"N, 83²9'59"W $\left.10^{\circ} 21^{\prime} 17^{\prime \prime N}, 8^{\circ} 23^{\prime 2} 29^{\prime \prime W}\right)$, Limón Province, northeast Caribbean coast of Costa Rica. June to September 2003 and 2004.

\section{Site of Infection}

Heart.

\section{Prevalence and Intensity of Infection}

Five of 40 turtles sampled (12.5\%). Mean intensity, 1.6; range, 1-2.

\section{Specimens Deposited}

HWML 48242; USNPC 97476, 97477, 97478; CHCR $278,279,280$.

\section{Additional Records}

Chelonia mydas in the Arabian Sea, near the Kiamari coast at Karachi, Pakistan [7]; C. mydas in Ubatuba, on the north coastline region of São Paulo State, Brazil (June 2006 and June 2007) [4].

\section{DISCUSSION}

Price [8] erected the genus Learedius (Spirorchiidae) and described 2 new species, L. learedi and L. similis. Both species descriptions were based on the single specimen obtained from the circulatory system of a green turtle, which was died in the National Zoological Park of Washington (U.S.A.). Price [8] transferred Distoma constrictum, Leared, 1862 to Learedius, and proposed a new name, L. europaeus, for it. Mehra [7] described Monticellius to contain M. indicum on the basis of a single fluke collected from the heart ventricle of a green turtle caught in the Arabian Sea, Pakistan. In the same paper, he described Learedius orientalis and transferred L. similis to Monticellius. Finally, Learedius loochooensis was described by Takeuti [9]. However, Dyer et al. [10] and Inohuye-Rivera et al. [2] suggested that $L$. learedi and $L$. orientalis could be synonymous.

According to Mehra [7], Monticellius differs from Learedius by having a smaller size and different body shape, a much shorter esophagus, the intestinal bifurcation closer to acetabulum, no intestinal caeca loops at their origin, different shape, number and arrangement of the testes, different shape, size and cirrus sac arrangement and different ovary shape. Monticellius indicum differs from $M$. similis by the absence of spines or verrucae, different oral sucker shape, different ratio of the size of the 2 suckers, smaller numbers and di- verse arrangement of testes, and better developed vitellaria [7].

Our comparison with Mehra's [7] fluke was based on his original description because there is no evidence that he deposited the type material in any available collection. Our specimens have a longer esophagus; an acetabulum armed with a single circle of minute spines, not mentioned by Mehra [7], and lobed testes (5 in 2 specimens and 6 in 3 specimens). In a single fluke (USNPC 97477), the exact number was not ascertainable because the testes were strongly overlapped. Mehra [7] described the egg of $M$. indicum as "...large with narrow, somewhat curved or hookshaped prolongations at both ends...". Probably the single egg observed [7] was in a poor condition or incompletely developed. From the 8 specimens collected, we observed a total of 7 eggs, but only 2 were in a good enough condition to be described. The eggs observed in our flukes have features different from all other spirorchiid eggs known to date, from the marine turtles. Despite these differences and the variation noted above, we prefer to place these specimens within $M$. indicum until more material is available for study, preferably including specimens from the type locality. Basic morphological data from the 3 specimens from Brazil [4] was similar to Mehra's [7] specimen except for the body length and esophagus features.

\section{ACKNOWLEDGEMENTS}

We wish to thank the Tortuguero Conservation Area and the Park Rangers for a logistic support and to facilitate the sampling on the beach. The manuscript was improved by comments and advices from Mr. John M. Kinsella (Helm West Laboratory, Missoula, Montana, U.S.A.). Research activities at the Tortuguero National Park were conducted under permission 091-2003-OFAU from Ministry of Environment and Energy and from the National System of Conservation Areas of Costa Rica.

\section{REFERENCES}

[1] Smith JW. The blood flukes (Digenea: Sanguinicolidae and Spirorchiidae) of cold-blooded vertebrates: part. 2. Helminthol Abstr 1997; 66: 329-44.

[2] Inohuye-Rivera RB, Cordero-Tapia A, Arellano-Blanco J, Gardner S. Learedius learedi Price, 1934 (Trematoda: Spirorchiidae), in black turtle (Chelonia mydas agassizii) hearts from Magdalena Bay, Baja California Sur, Mexico. Comp Parasitol 2004; 71: 37-41.

[3] Platt TR. Family spirorchiidae stunkard 1921. In: Gibson DI, Jones A, Bray RA, Eds. Keys to the Trematodes, London: CAB International and The Natural History Museum 2002; Vol. 1, pp. 453-67.

[4] Werneck MR, Gallo BMG, da Silva RJ. First report of Monticellius indicum Mehra, 1939 (Digenea: Spirorchiidae) infecting Chelonia mydas Linnaeus, 1758 (Testudines: Chelonidae) from Brazil. Braz J Biol 2008; 68: 455-6.

[5] Greiner EC, Forrester JJ, Jacobson ER. Helminths of mariculturereared green turtles (Chelonia mydas) from Grand Cayman, British West Indies. Proc Helminthol Soc Wash 1980; 47: 142-4.

[6] Bush AO, Lafferty KD, Lotz JM, Shostak AW. Parasitology meets ecology on its own terms: Margolis et al. revisited. J Parasitol 1997; 83: 575-83.

[7] Mehra HR. New blood flukes of the family Spirorchiidae Stunkard (Trematoda) from the marine turtle Chelone mydas of the Arabian Sea with observations on the synonymity of certain genera and classification of the family. Proc Natl Acad Sci India 1939; 9: 15567.

[8] Price W. New genera and species of blood flukes from a marine turtle, with a key to the genera of the family Spirorchiidae. J Wash Acad Sci 1934; 24: 132-41. 
[9] Takeuti E. New blood flukes of the family Spirorchiidae from Japanese freshwater tortoise and marine turtles. Jpn J Med Sci 1942; $2: 161-74$

[10] Dyer WG, Williams EH, Jr, Bunkley-Williams L. Angiodictyum mooreae n. sp. (Digenea: Microscaphidiidae) and other digeneans from an atlantic hawksbill turtle Eretmochelys imbricata from Puerto Rico. J Aquat Anim Health 1995; 7: 38-41.

Received: November 25, 2008

(C) Santoro et al.; Licensee Bentham Open.

This is an open access article licensed under the terms of the Creative Commons Attribution Non-Commercial License (http://creativecommons.org/licenses/by-nc/3.0/) which permits unrestricted, non-commercial use, distribution and reproduction in any medium, provided the work is properly cited. 